\title{
Toxicological Tests of Tumolit and Artemisinin Products on Laboratory Mice and Rats
}

\author{
Crina Elena OROIAN (STRUGARIU) ${ }^{1}$, Anca Alexandra STUPARU ${ }^{1)}$, Voichita Maria GAVRILA'), \\ Teofil OROIAN ${ }^{1) *}$ \\ ${ }^{1)}$ Department of Fundamental Sciences, Faculty of Animal Science and Biotechnologies, University of \\ Agricultural Sciences and Veterinary Medicine, 3-5 Mănăştur Street, 400372 Cluj-Napoca, Romania \\ *Corresponding author, e-mail: teoroian@yahoo.com
}

Bulletin UASVM Animal Science and Biotechnologies 72(2) / 2015

Print ISSN 1843-5262; Electronic ISSN 1843-536X

DOI:10.15835/buasvmcn-asb: 11427

\begin{abstract}
This paper presents the experimental results establishing the lethal dose (LD) of the two products considered to have antitumor effect:Tumolit and Artemisinin.

For testing, we used an experimental design including two species of gnawers, Swiss mice and Wistar rats. Two experimental groups were used, consisting of 20 Swiss male mice each, as well as two groups of 10 Wistar rats/lot. In interpreting the results of the research and in the development of the experimental protocol, we took into account the toxicity scale after Hodge and Sterner. Initial doses were usedof both products at $200 \mathrm{mg} / \mathrm{kg} /$ body for each mouse and rat, respectively, administered orallyin single-doses. Between each oral dose, there was one day of rest in order to evaluate possible effects. As mentioned in theProtocol, the dose was increased to500 mg dose / kg / body,then to $1000 \mathrm{mg} / \mathrm{kg} /$ body, $2000 \mathrm{mg} / \mathrm{kg}$ / body and then to $5000 \mathrm{mg} / \mathrm{kg} /$ body. At this last dose, administration was disrupted in mice. For rats, doses were further increased in three innings to $5000 \mathrm{mg} / \mathrm{kg} /$ body, $15,000 \mathrm{mg} / \mathrm{kg}$ / body concerned $20,000 \mathrm{mg} / \mathrm{kg}$ / body in single oral dose. The administration was done by gavage in a single dose. There were no toxicity effects reported at any dose level applied, which is why we conclude that the two products are practically non-toxic.
\end{abstract}

Keywords: Artemisinin, mice, rats, tests, toxicity, Tumolit.

\section{INTRODUCTION}

In this paper, we present the experimental results on the median lethal dose $\left(\mathrm{LD}_{50}\right)$ of the two products considered to have antitumor effect: Tumolit and Artemisinin (producers 'prospectParapharm, Cluj; Houet al., 2008; Lai et al., 2013, Das, 2015).

Artemisinin is the active substance in the plant Artemisia annua, known as sweet wormwood (Efferth and Kaina, 2010). From a chemical point of view, Artemisinin is a sesquiterpene lactone with an endoperoxide bridge composed of three isoprene units and a lactone ring (www.ebi.ac.uk).

Tumolit, a dietary supplement considered by producer (Parapharm Cluj) to have antitumor effect, has the following composition: arginine, vitamin C, L-phenylalanine, L-histidine, D,
L-methionine, malic acid, L-tryptophan, adenine, L-tyrosine, vitamin B6, vitamin B2, biotin, iron , zinc, magnesium, manganese, copper, molybdenum, vanadium, nickel, boron, fluorine, cobalt (according to information provided by the producer - Parapharm Cluj).

The lethal dose (LD) indicates an acute toxicity of substances that enter the body orally or parenterally, representing the minimum dose of the substance that causes the death of an adult animal. The lethal dose is established on an animal experimental batch and marked with DL followed by an index - from 1 to 100- indicating the percentage of lethality, at a given time; the expression is in $\mathrm{mg} / \mathrm{kg}$ body weight (Gofita, 2011). 
The variation in individual response to lethal doses of a substance required input values (Danila et al., 1984): $\mathrm{DL}_{5}$ (DLM) = minimum lethal dose, $\mathrm{LD}_{50}(\mathrm{DML})=$ median lethal dose, $\mathrm{DL}_{75}=$ fatal dose, $\mathrm{DL}_{100}=$ maximum lethal dose (absolute lethal dose), $\mathrm{DL}_{0}=$ maximum tolerated dose (with toxic effects but not fatal), often used in practice, it isnot actually a lethal dose.

Typically, in order to express the acute toxicity of a substance, the $\mathrm{LD}_{50}$ category is used (mg / $\mathrm{kg}$ ), because at this dose, individual reactivity differences are lower.This is a virtual value, obtained by statistical calculation, not a biological constant. Many factors can influence the toxicity, thus affecting the expression $\mathrm{LD}_{50}$ Such factors include animal breed, age and weight, the nature of food, environmental conditions, absence of feeding before performing the test, the method of administration, the volume and nature of conditioning the environment, duration of animal observation. Because of these variables, for many purposes it is sufficient only to determine the order of magnitude for $\mathrm{LD}_{50}$ (eg. between 5 and 50 $\mathrm{mg} / \mathrm{kg}$ body weight and $500 \mathrm{mg} / \mathrm{kg}$, etc.), not the absolute value (Gofita, 2011). In relation to $L_{50}$ we can classify and compare toxic substances.

Lethal dose 50 is usually determined on laboratory animals such as mice, rats, rabbits, guinea pigs.Although other tests are under development, which may, to some extent, replace the current form test, classical measures are still among the most important in measuring toxicity. Many events led to the implementation and further use of these tests, although the test population is significantly reduced compared to their original size (Encyclopaedia of Toxicology, 2014). Result evaluation for our research was done according to Hodge and Sterner toxicity scale shown below (tab.1).

\section{MATERIALS AND METHODS}

In practice, a lethal dose is recognized according to three coordinates: - minimum$\mathrm{DL}_{25}$, - medium - $\mathrm{DL}_{50}$ and maximum- $\mathrm{DL}_{100}$. In our research, we tried to establish $\mathrm{LD}_{50}$, which represents the dose at which death occurs in 50\% of experimental animals.

The purpose of these measurements was to establish a possibly toxic or even lethal effect of the two products administered, Tumolit or Artemisinin, a dose-dependent effect.Knowing that toxicity depends on exposure to the toxic compound, and this is, in turn, determined by the dose and duration of exposure, we tried to assess this risk by establishing $\mathrm{LD}_{50}$ and monitoring all parameters that could, in some way, influence the average lethal dose determination.

The material studied was Tumolit, a dietary supplement, and Artemisinin, regarded as having antitumor effect (Golenser et al., 2006).

For each type of supplement tested, there was one experimental group consisting of 20 mice of a Swiss variety and 10 Wistar male rats.The experimental groups were kept under identical conditions of temperature $\left(22^{\circ} \pm 0.5^{\circ} \mathrm{C}\right)$ program of 12/12 hour light-dark, ad libidum feeding fodder, a granulated product provided by the Cantacuzino Institute, which has the following composition: corn, soybean meal, sunflower meal, calcium carbonate, calcium phosphate, amino acids, salt, vitamin-mineral premix and water ad libidum. Tests were conducted in the Quantum Pharm company laboratory, Cluj-Napoca.

As a novelty, in our research we used a toxicity test progressively, from low doses to high doses. The advantage of this method is that it reduces the number of units required for experimental testing, avoids losses, duplication of testing on other individuals and groups.

Tab.1. Hodge and Sterner Toxicity Scale- Group- Toxicity Degree $\mathrm{DL}_{50}$ - single oral dose/rat

\begin{tabular}{ccc}
\hline Toxicity Group & Toxicity Degree & DL50 - single oral dose $/$ rat \\
\hline 1 & extremely toxic & under $1 \mathrm{mg} / \mathrm{kg}$ \\
\hline 2 & very toxic & $1-50 \mathrm{mg} / \mathrm{kg}$ \\
\hline 3 & moderately toxic & $50-500 \mathrm{mg} / \mathrm{kg}$ \\
\hline 4 & low toxicity & $500-5000 \mathrm{mg} / \mathrm{kg}$ \\
\hline 5 & practically nontoxic & $5000-15000 \mathrm{mg} / \mathrm{kg}$ \\
\hline 6 & relatively nontoxic & over $15000 \mathrm{mg} / \mathrm{kg}$ \\
\hline
\end{tabular}


The doses used were administered with a 48-hour difference, considering that their effect will fade in this time.The experiment lasted nine days on mice and 11 days on rats. Tumolit administration, as well as the product Artemisinin doses / mice / rats as shown in Table 2.3 was made orally by esophageal gavage, the product was mixed with distilled water in the amount of $0.5 \mathrm{ml} /$ mouse and $1 \mathrm{ml} /$ rat.The doses per day were: (tab.2) (Table 3)

During the test, the behaviour of individual groups and the experimental units was observed, in terms of clinical signs of intoxication and body weight by weighing.

\section{RESULTS AND DISCUSSION}

At an amount of $6 \mathrm{mg} /$ mouse or $28 \mathrm{mg} /$ rat in both Tumolit and Artemisinin, there were no reported changes in group or individual behaviour or appetite.

The same observations resulted at a dose of 30 $\mathrm{mg} / \mathrm{mouse}$ and $140 \mathrm{mg} / \mathrm{rats}$, administered on day five and recorded until the seventh day, whereas Artemisinin, administered at $60 \mathrm{mg} /$ mouse which corresponds to $2000 \mathrm{mg} / \mathrm{kg} /$ body, and $280 \mathrm{mg}$
/ rat, in both species led to a tremor manifested by continuous motion in the first two hours following administration.There were no other events typical of a chemical poisoning, whereas the appetite was normal, although we found a slight reduction in weight for all individuals.The signs of agitation disappeared in the first 24 hours after administration, and in the next 24 hours, the behaviour returned to normal.The same signs and behaviours can be reported in Artemisinin to an amount of $150 \mathrm{mg} / 700 \mathrm{mg}$ for mice/rats, respective.Tumolit did not lead to behavioural changes or weight loss.There were no clinical signs of intoxication with any of the products administered.

During the 11 days of the experiment there was no mortality. After testing, both groups of mice and rats were observed for 14 days to determine if any signs of late intoxication could occur.During this period the same type of feed was administered, we used the same conditions of light, temperature and water at discretion.In this interval, follow-up post-test animals exhibited normal behaviour without any clinical changes.

Tab. 2. The doses of the product Tumolit used in the experiments

\begin{tabular}{ccccc}
\hline Day & $\begin{array}{c}\text { Dose mg/kg/ } \\
\text { body }\end{array}$ & Dose/Mice Swiss(mg) & $\begin{array}{c}\text { Dose/Rats } \\
\text { Wistar(mg) }\end{array}$ & Obs. \\
\hline 1. & $200 \mathrm{mg}$ & $6 \mathrm{mg}$ & $28 \mathrm{mg}$ & Without clinical signs \\
\hline 3. & $500 \mathrm{mg}$ & $15 \mathrm{mg}$ & $70 \mathrm{mg}$ & Without clinical signs \\
\hline 5. & $1000 \mathrm{mg}$ & $30 \mathrm{mg}$ & $140 \mathrm{mg}$ & Without clinical signs \\
\hline 7. & $2000 \mathrm{mg}$ & $60 \mathrm{mg}$ & $280 \mathrm{mg}$ & Without clinical signs \\
\hline 9. & $5000 \mathrm{mg}$ & $150 \mathrm{mg}$ & $700 \mathrm{mg}$ & Without clinical signs \\
\hline 11. & $10,000 \mathrm{mg}$ & - & $1400 \mathrm{mg}$ & Without clinical signs \\
\hline
\end{tabular}

Tab. 3. The doses of the product Artemisinin usedin the experiments

\begin{tabular}{ccccc}
\hline Day & Dose $\mathrm{mg} / \mathrm{kg} /$ body & Dose/Mice Swiss(mg) & Dose/Rats Wistar(mg) & Obs. \\
\hline 1. & $200 \mathrm{mg}$ & $6 \mathrm{mg}$ & $28 \mathrm{mg}$ & Without clinical signs \\
\hline 3. & $500 \mathrm{mg}$ & $15 \mathrm{mg}$ & $70 \mathrm{mg}$ & Without clinical signs \\
\hline 5. & $1000 \mathrm{mg}$ & $30 \mathrm{mg}$ & $140 \mathrm{mg}$ & Without clinical signs \\
\hline 7. & $2000 \mathrm{mg}$ & $60 \mathrm{mg}$ & $280 \mathrm{mg}$ & $\begin{array}{c}\text { Agitation, without clinical } \\
\text { signs, weight loss }\end{array}$ \\
\hline 9. & $5000 \mathrm{mg}$ & $150 \mathrm{mg}$ & $700 \mathrm{mg}$ & $\begin{array}{c}\text { Agitation, without clinical } \\
\text { signs, weight loss }\end{array}$ \\
\hline 11. & $10000 \mathrm{mg}$ & - & $1400 \mathrm{mg}$ & $\begin{array}{c}\text { Agitation, without clinical } \\
\text { signs, weight loss }\end{array}$ \\
\hline
\end{tabular}




\section{CONCLUSIONS}

1. The Tumolit product in the aforementioned dose did not produce any change in the experimental units.

2. The Artemisinin product determined, at the starting dose of $2000 \mathrm{mg} / \mathrm{kg} /$ body, mild manifestations of agitation, stagnation or slight reduction in body weight without any specific signs of intoxication.

3. We conclude that neither Tumolit, nor Artemisinin produce toxicity at a dose of 500 $\mathrm{mg} / \mathrm{kg} / \mathrm{body}$, which allows us to state that they present no toxicity.

Aknowledgment: This paper was published under the frame of European Social Fund Human Resources Development Operational Programme 2007-2013, Project No.POSDRU/159/1-5/S/1327

\section{REFERENCES}

1. Dănilă G, Cotrau M, Nechifor M. (1984), Ghid de date toxicologice, EdituraMedicală, București
2. Das AK (2015) Anticancer Effect of AntiMalarial Artemisinin Compounds Annals of Medical and Health Sciences Research. 5 (2) 93-102

3. Efferth T, Kaina B (2010), Toxicity of the antimalarial artemisinin and its derivate, Critical Reviews in Toxicology, 40 (5) 405-421,

4. Eliza Gofita, (2011), Toxicologie, Editura Medicala Universitara Craiova,

5. Golenser J, Waknine JH, Krugliak M, Nicholas HH,Grau GE. (2006) Current perspectives on the mechanism of action of artemisinins, International Journal for Parasitology 36 $1427-1441$

6. Hou J, Wang D, Zhang R, Wang H (2008). Experimental therapy of hepatoma with artemisinin and its derivatives: in vitro and in vivo activity, chemosensitization, and mechanisms of action. Clin Cancer Res 14 (7): 5519-5530. doi:10.1158/1078-0432.CCR-08-0197

7. Lai H, Singh NP, Sasaki T. (2013) Development of artemisinin compounds for cancer treatment. Invest New Drugs 31:230-246.

8. *** Encyclopedia of Toxicology, (2014 ), Third Edition, pages 58-60

9. *** www.ebi.ac.uk 